\title{
ECOLOGY OF THE FACULTATIVE PHYTOTELMIC CRAB PLATYCHIRARMA BUETTIKOFERI (DE MAN, 1883) (DECAPODA, BRACHYURA, SESARMIDAE)
}

\author{
BY
}

\begin{abstract}
MARCO FUSI ${ }^{1,2,8,9}$ ), JOSEPH BAYI ${ }^{3}$ ), VANESSA NGO-MASSOU ${ }^{3}$ ), NDONGO DIN ${ }^{3}$ ), ANGELA SACCHI ${ }^{4}$ ), FARID DAHDOUH GUEBAS ${ }^{5,6,10}$ ) and STEFANO CANNICCI ${ }^{1,7,8,11}$ )

1) Department of Biology, University of Florence, Via Madonna del Piano 6, Sesto Fiorentino, I-50019 Florence, Italy

2 ) Edinburgh Napier University, School of Applied Sciences, Edinburgh, EH11 4BN, U.K.

${ }^{3}$ ) The University of Douala, Faculty of Science, Department of Botany, P.O. Box 8948, Douala, Cameroon

4 ) University Cattolica del Sacro Cuore, Faculty of Agricultural Sciences, Agricultural and Environmental Chemistry Institute, Via Emilia Parmense 84, I-29100 Piacenza, Italy

5 ) Laboratory of Systems Ecology and Resource Management, Department of Organism Biology, Faculty of Sciences, Université Libre de Bruxelles - ULB, Avenue F.D. Roosevelt 50, CPI 264/1, B-1050 Brussels, Belgium

6) Laboratory of Plant Biology and Nature Management, Department of Biology, Faculty of Sciences and Bio-engineering Sciences, Vrije Universiteit Brussel - VUB, Pleinlaan 2, B-1050 Brussels, Belgium

${ }^{7}$ ) The Swire Institute of Marine Science and The School of Biological Sciences, The University of Hong Kong, Pokfulam Road, Hong Kong, Hong Kong S.A.R.
\end{abstract}

\begin{abstract}
The mangrove forests surrounding Douala, Cameroon, have a long history of human impact due to rapid urbanization, resulting in patches of true mangrove forest interspersed with areas dominated by the mangrove-associated Pandanus species. A survey carried out to assess the possible shift in crab fauna composition and dominance between mangrove and Pandanus dominated areas revealed an undescribed phytotelmic habitat for Platychirarma buettikoferi. This species was found colonizing the natural reservoirs of fresh water represented by Pandanus spp. Our results show $P$. buettikoferi to be ecologically dependent upon Pandanus spp., and absent on the mangrove floor and trees, strongly indicating a phytotelmic adaptation. Our data suggest that this species is a facultative phytotelmic species well adapted to Pandanus spp. dominated areas. Further studies on the reproductive biology and feeding behaviour of $P$. buettikoferi may shed light on this unique phytotelmic lifestyle and its role in mangrove ecosystem functioning.
\end{abstract}

\footnotetext{
8) Corresponding authors; e-mail: cannicci@hku.hk; marco.fusi@kaust.edu.sa

${ }^{9}$ ) ORCID: https://orcid.org/0000-0001-7433-2487

${ }^{10}$ ) ORCID: https://orcid.org/0000-0002-5906-8996

11 ) ORCID: https://orcid.org/0000-0002-6544-0213
} 
Key words. - Ecological degradation, phytotelma, sesarmid crabs, mangrove ecology

\section{RÉSUMÉ}

Les forêts de mangroves entourant Douala, au Cameroun, ont une longue histoire d'impacts humains en raison de l'urbanisation rapide. Celle-ci résulte en des parcelles de forêt de mangrove entrecoupées de zones dominées par Pandanus, espèce associée à la mangrove. Une étude faite pour évaluer le changement dans la composition faunistique de crabes et la dominance entre les zones dominées par les mangroves et les Pandanus a révélé un habitat phytotelmique pour Platychirarma buettikoferi, jamais décrit auparavant. Cette espèce a été trouvée en train de coloniser les réservoirs naturels d'eau douce représentés par Pandanus spp. Nos résultats montrent que P. buettikoferi est écologiquement dépendant de Pandanus spp., et absent du sol et des arbres de la mangrove, ce qui indique fortement une adaptation phytotelmique. Nos données suggèrent que cette espèce est une espèce phytotelmique facultative bien adaptée aux zones dominées par Pandanus spp. D'autres études sur la biologie reproductive et le comportement alimentaire de P. buettikoferi pourraient documenter ce mode de vie phytotelmique unique, ainsi que son rôle dans le fonctionnement de l'écosystème de la mangrove.

\section{INTRODUCTION}

Human activity is known to have detrimental impacts on the whole mangrove ecosystem (Ellison, 2008; Saenger, 2012), especially through deforestation (Hutchison et al., 2014), uncontrolled sewage discharge from urban areas (Mohamed et al., 2008; Cannicci et al., 2009; Bartolini et al., 2011; Penha-Lopes et al., 2011) and global warming (Ellison \& Cannicci, 2016). These impacts can significantly transform the forests, triggering a negative cascade effect on the whole ecosystem assemblage leading to a reduction of biodiversity and functionality (Valiela et al., 2001; Worm et al., 2006; Duke et al., 2007; Halpern et al., 2008; Butchart et al., 2010; Fusi et al., 2016).

The Wouri River Estuary in Cameroon is one of the most thriving mangrove ecosystems in West Africa (UNEP, 2007); but, due to population growth and shipping activity in Douala harbour and to an oil platform close to the Gulf of Guinea, it is also one of the most impacted (Scheren, 2002; Alemagi, 2007). In particular, rapid population growth in Douala has led to large-scale deforestation due to a growing demand for housing and logging cultivation (Saenger et al., 2008; Nfotabong-Atheull et al., 2009, 2011, 2013).

This urbanization has transformed hectares of forest dominated by mature mangrove trees, such as Rhizophora spp. and Avicennia germinans (L.) Stearn, 1764, into highly degraded areas with a dramatic change in botanical assemblages (Din \& Baltzer, 2008; Nfotabong-Atheull et al., 2011). In many of the affected areas, the mangrove-associated screw-pines of the genus Pandanus (Tomlinson, 1986) rapidly took over and are now the dominant species to appear in the 
vegetation secondary succession. Pandanus spp. (Pandanaceae) are known to shelter animals from predators, such as the micro-mammal Sminthopsis virginiae de Tarragon, 1847 (Braithwaite \& Lonsdale, 1987), and to provide a suitable habitat for many birds (Verbeek et al., 1993). They also have an important role in the feeding ecology of terrestrial decapods such as Cardisoma carnifex Herbst, 1796, and Birgus latro Linnaeus, 1767 (Grubb, 1971; Lee, 1985).

Screw-pines, similarly to the New World bromeliads, are phytotelms (i.e., with structures that retain rainwater), providing micro-aquatic environments in their leaf axils for a wide variety of animals, including some reptiles and amphibians (Laessle, 1961; Fish, 1983). Crabs are also known to inhabit phytotelmata. In Madagascar, Malagasya goodmani Cumberlidge, Boyko \& Harvey, 2002, and Labuanium gracilipes $\mathrm{H}$. Milne Edwards, 1854, were found to be associated with Pandanus (Cumberlidge et al., 2002). Likewise, in the West Pacific the genus Scandarma Schubart, Liu \& Cuesta, 2003 has been described thriving in Pandanus, e.g., S. lintou Schubart, Liu \& Cuesta, 2003 in Taiwan. These species disclose biological traits similar to Metapaulias depressus Rathbun, 1896 and Geosesarma spp. that are known to live as phytotelmic species (see review in Cumberlidge et al., 2005).

A recent survey of Cameroonian mangroves described a high biodiversity of macrobenthonic brachyuran crabs belonging to the family Sesarmidae (see Fusi et al., 2016). Of the eight species found to inhabit the mangroves and adjacent habitats, Platychirarma buettikoferi (De Man, 1883) appeared to be frequently associated with Pandanus trees. The present study was designed to investigate the possible phytotelmic association of P. buettikoferi with Pandanus trees of the Wouri estuary and the changes in population dynamics resulting from the ecological shift from mangrove to screw-pine dominated forests.

\section{MATERIAL AND METHODS}

Species studied

Platychirarma buettikoferi (Sesarmidae Dana, 1851) has been recorded along the West African coast from Liberia to Angola (Manning \& Holthuis, 1981). The species is easily recognized by its characteristic purplish blue flat chelipeds with red tips (in live animals). Brightly coloured male chelipeds, in particular, are important for signalling females (Manning \& Holthuis, 1981). The species is usually found in the landward part of true mangrove forests, beyond the area reached by the highest high tides (see Rathbun, 1921: 450). Ovigerous females were reported in March, June, July-August, and October-December (Rathbun, 1921; Rossignol, 1957; Manning \& Holthuis, 1981). In Cameroon, P. buettikoferi 
has been recorded under the humid leaf litter found on the banks of a riverine forest close to the sea in Kribi and in the Wouri estuary mangrove forests (Fusi et al., 2016).

\section{Study area}

This study was carried out in and around the mangrove forests of the Wouri River estuary, one of the largest estuaries in West Africa, surrounding the city of Douala, Cameroon (fig. 1). The climate is equatorial, and the area receives high rainfall, on average about $4000 \mathrm{~mm}$ per year. Most of the rain falls between MarchNovember (rainy season), with a short dry season often punctuated by showers in December-February. The humidity is high year-round (approximately 100\%).

The survey was performed in September and October 2009 in two forests: Wouri Bridge, hereafter abbreviated to WB $\left(4^{\circ} 4^{\prime} 19^{\prime \prime} \mathrm{N} 9^{\circ} 42^{\prime} 58^{\prime \prime} \mathrm{E}\right)$, and Essengue, hereafter abbreviated to ES $\left(4^{\circ} 53^{\prime \prime} \mathrm{N} 9^{\circ} 40^{\prime} 39^{\prime \prime} \mathrm{E}\right)$. WB is located north of Douala, close to the bridge crossing the Wouri River. Part of this forest was cleared 20 years ago for construction of the bridge and currently the whole forest has regrown with extended patches of Pandanus candelabrum P. Beauv. associated with mature forest dominated by Avicennia sp. and Rhizophora spp. (Din \& Baltzer, 2008).

ES forest, located south of Douala at the edge of the harbour, was recently affected by clearing due to rapid development of the commercial port. This forest is colonized by several species of mangrove-associated flora (Nfotabong-Atheull et al., 2013), including Nypa fruticans (Thunb.) Wurmb., Guibourtia demensei Harms, and P. candelabrum.

The locality of Bois des Singes $\left(4^{\circ} 0^{\prime} 49^{\prime \prime} \mathrm{N} 9^{\circ} 40^{\prime} 28^{\prime \prime} \mathrm{E}\right)$, hereafter BS, located southwest of Douala, was also considered since there no Pandanus spp. were found. Similarly to WB, BS is a mature forest manly dominated by Rhizophora racemosa Meyer, 1818, Rhizophora mangle L., 1764, and Rhizophora harrisonii Leechman, 1918. We considered this forest as a control to verify the exclusive relationship between P. buettikoferi and Pandanus candelabrum.

\section{Sampling}

A total of 49 specimens of Pandanus spp. (39 in WB and 10 in ES; fig. 2) were randomly chosen along two transects in each forest. For every plant, we checked the phytotelmata present and recorded the number of crabs, the crabs' species, each crab's sex and the height above the ground of the inhabited phytotelmic microhabitat. In cases where specimens were small and it was not possible to determine their sex, they were classified as juveniles. We then categorized the phytotelmata into three categories: 0-100, all animals found within the first $100 \mathrm{~cm}$ 

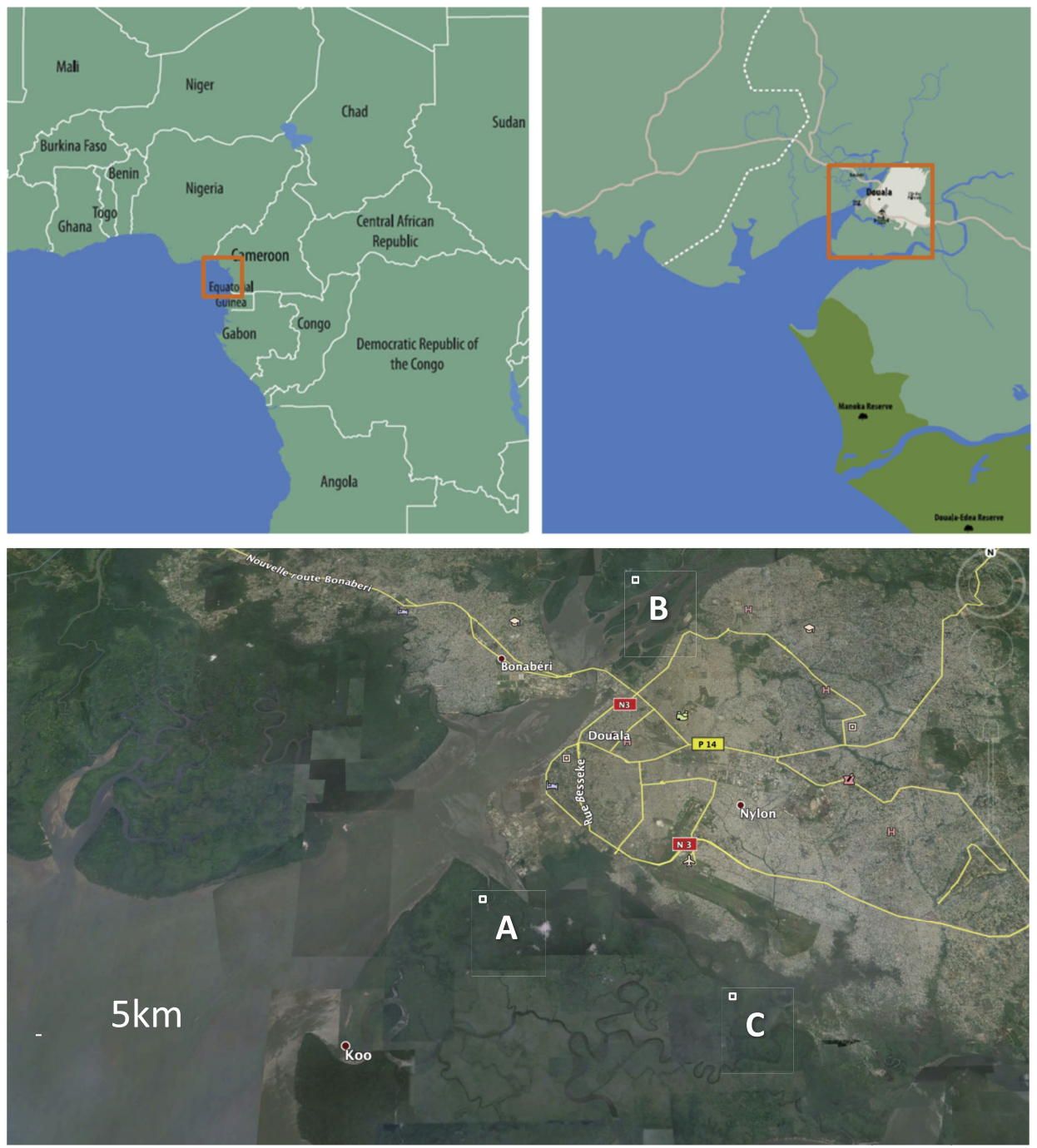

Fig. 1. The study site in Cameroon, showing the location of the survey in three steps of increasing detail, with indicated: A, Essengue mangrove forest; B, Wouri Bridge mangrove forest; C, Bois de Singes mangrove forest.

from the ground (the lowest leaf axils were recorded at $10 \mathrm{~cm}$ above ground); 101200, all animals found between $101 \mathrm{~cm}$ and $200 \mathrm{~cm}$; and $>200 \mathrm{~cm}$, all animals recorded at heights greater than $200 \mathrm{~cm}$.

To assess the overall composition of brachyuran fauna, and eventually verify the exclusive association of $P$. buettikoferi with Pandanus candelabrum, two random transects (100-500 m apart) were established in each vegetation belt (Rhizophora, Pandanus or Avicennia dominated) in each forest. Along each transect, three $2 \times$ 

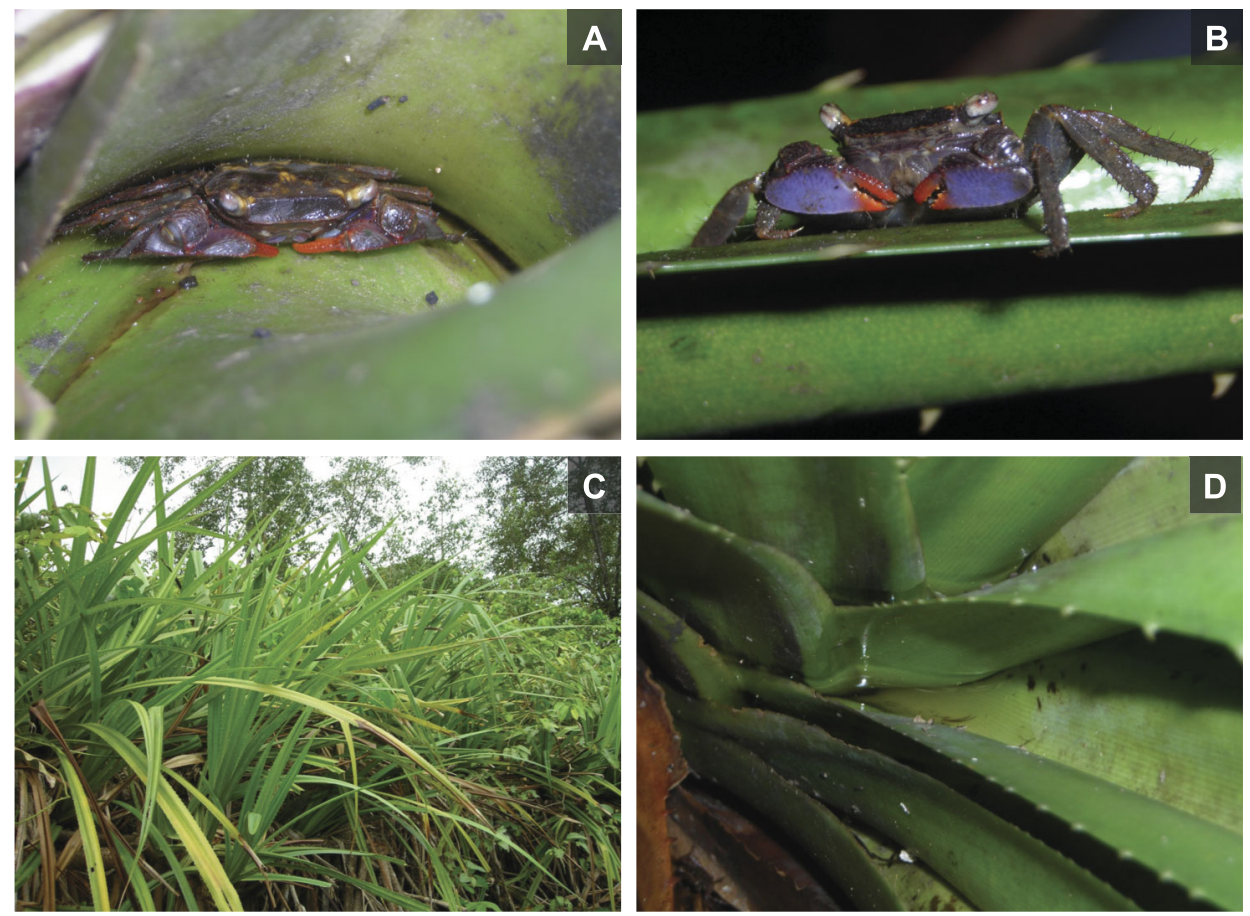

Fig. 2. A, Platychirarma buettikoferi (De Man, 1883) (male) in a leaf axil; B, ditto, note the distinct, flat frontal part of the chelae; C, Pandanus candelabrum P. Beauv. leaf cluster complex, which typically dominates the first succession in cleared mangrove forests; D, ditto, leaf axil filled with water.

$2 \mathrm{~m}^{2}$ quadrats were randomly sampled to assess the abundance and density of the brachyuran populations. Based on the complexity of the habitat and the varied behaviour of the studied species, different sampling techniques were used to assess the abundance of the various groups of macrofauna (for more information about the sampling methodology see Skov et al., 2002; Fusi et al., 2016). For safety reasons, this survey could not be performed for the ES forest.

Sediment water and leaf axil water temperature, conductivity, and $\mathrm{pH}$ were recorded by performing in situ measurements with measuring sensors (Acorn $\mathrm{pH}$ 6 meter Oakton Instruments ${ }^{\circledR}$, Vernon Hills, IL, U.S.A.). These three variables are important because they affect the physiology of the animals. Temperature is one of the most important variables defining the metabolism of animals and is crucial for ectotherms whose body temperature matches the environmental temperature, and therefore it governs the biochemical processes of the animals. Conductivity indicates the presence of solutes in the water. Finally, $\mathrm{pH}$ is very important for crabs because it can affect their exoskeleton by dissolving the calcium carbonate structures. The amount of leaf axil water retrieved was 10- 
$20 \mathrm{ml}$. Crab specimens collected from phytotelmata were identified using Monod (1956) and the nomenclature reviewed following Shahdadi et al. (2019); sex and reproductive stage (ovigerous or non-ovigerous) were recorded and photographed. Ten specimens were stored in alcohol (70\%) and deposited in the Zoological Collection of the Museum of Zoology of the University of Florence.

PERMANOVA (Anderson et al., 2008) was used to test the null hypothesis of no differences in P. buettikoferi population characteristics, $\mathrm{pH}$ and conductivity across the factors Site (fixed, orthogonal, two levels: WB - Wouri Bridge and ES Essengue) and Transect (random, nested in Site, 2 levels). Statistical analyses were performed using the software PRIMER 6 (Anderson et al., 2008).

\section{RESULTS}

We recorded a significantly different assemblage of Platychirarma buettikoferi in the two sites (PERMANOVA: $F=7.41$; $\mathrm{df}=1.46 ; p<0.01$ ), but no significant differences among the three categories of leaf axil height where the species was found. P. buettikoferi was persistently present in all the 49 leaf axils of Pandanus candelabrum examined.

A similar number of males, females and ovigerous females were found in every leaf cluster analysed from WB forest (average $4.7 \pm 0.7$ individuals), evenly distributed among sexes, and no statistical differences were detected among different height classes (table I; fig. 3). In ES forest, an average of $9.6 \pm 1.37$ individuals was recorded evenly distributed among the height classes, with a more pronounced variability of sex ratio distribution. No other species were found in the leaf axils, except for one individual sesarmid Armases elegans (Herklots, 1851) (0-100 $\mathrm{cm}$ height in WB) and one individual of a centipede (Scolopendridae, 0$100 \mathrm{~cm}$ height in ES). Despite the presence of other crab species, no specimens of P. buettikoferi were found on the forest floor, in either the Pandanus vegetated belt, or in the Rhizophora and/or Avicennia belts (figs. 3, 4).

All water temperatures recorded were around $27.3 \pm 0.9^{\circ} \mathrm{C}$, with no differences between ground and axil water. Conductivity was significantly higher in phytotelmic water than in sediment water (fig. 5) (PERMANOVA, Conductivity: $F=10.638 ; \mathrm{df}=2.65 ; p<0.05)$, but $\mathrm{pH}$ was significantly lower in phytotelmic water than in sediment water (PERMANOVA, $\mathrm{pH}: F=22.503$; $\mathrm{df}=2.65$; $p<0.01$ ) both for the WB and ES forests.

\section{DISCUSSION}

Among the resident mangrove fauna, crabs and molluscs are undoubtedly the most important components in terms of abundance, biomass and their ecological 
TABLE I

Characteristics of the phytotelmic microhabitats occupied by the mangrove crab Platychirarma buettikoferi (De Man, 1863) (Sesarmidae) from the mangrove forests surrounding the city of Douala,

Cameroon

\begin{tabular}{|c|c|c|c|c|c|c|c|c|}
\hline Site & $\mathrm{pH}$ & $\begin{array}{l}\text { Conductivity } \\
(\mathrm{mV})\end{array}$ & $\begin{array}{l}\text { Height } \\
(\mathrm{cm})\end{array}$ & $\begin{array}{c}\text { Total } \\
\text { number of } \\
\text { specimens }\end{array}$ & Male & $\begin{array}{l}\text { Non-ovigerous } \\
\text { female }\end{array}$ & $\begin{array}{l}\text { Ovigerous } \\
\text { female }\end{array}$ & Juvenile \\
\hline Wouri Bridge & - & - & 106 & 3 & 2 & & 1 & \\
\hline Wouri Bridge & - & - & 80 & 4 & 2 & 2 & & \\
\hline Wouri Bridge & - & - & 110 & 2 & 1 & 1 & & \\
\hline Wouri Bridge & - & - & 204 & 3 & 1 & 1 & 1 & \\
\hline Wouri Bridge & - & - & 270 & 2 & & & 2 & \\
\hline Wouri Bridge & - & - & 290 & 3 & 1 & 2 & & \\
\hline Wouri Bridge & - & - & 100 & 3 & 1 & 1 & 1 & \\
\hline Wouri Bridge & - & - & 85 & 0 & & & & \\
\hline Wouri Bridge & - & - & 165 & 4 & 3 & 1 & & \\
\hline Wouri Bridge & - & - & 190 & 3 & 1 & 2 & & \\
\hline Wouri Bridge & - & - & 140 & 4 & 2 & 1 & 1 & \\
\hline Wouri Bridge & - & - & 120 & 3 & 1 & 1 & 1 & \\
\hline Wouri Bridge & - & - & 125 & 4 & 3 & 1 & & \\
\hline Wouri Bridge & - & - & 85 & 6 & 4 & & 2 & \\
\hline Wouri Bridge & - & - & 130 & 9 & 5 & 3 & 1 & \\
\hline Wouri Bridge & 6.34 & - & 120 & 7 & 3 & 1 & 3 & \\
\hline Wouri Bridge & 6.1 & - & 130 & 9 & 3 & 5 & 1 & 1 \\
\hline Wouri Bridge & - & - & 120 & 7 & 4 & 2 & 1 & \\
\hline Wouri Bridge & - & - & 90 & 4 & 2 & 2 & & 2 \\
\hline Wouri Bridge & - & - & 90 & 5 & 2 & 3 & & \\
\hline Wouri Bridge & - & - & 75 & 5 & 3 & 2 & & \\
\hline Wouri Bridge & - & - & 130 & 4 & 1 & 3 & & 1 \\
\hline Wouri Bridge & - & - & 110 & 7 & 4 & 2 & 1 & \\
\hline Wouri Bridge & - & - & 150 & 4 & 2 & 2 & & \\
\hline Wouri Bridge & - & - & 190 & 3 & 2 & 1 & & \\
\hline Wouri Bridge & 5.78 & 46 & 140 & 7 & 3 & & 4 & \\
\hline Wouri Bridge & 6.12 & 25 & 130 & 12 & 1 & 8 & 3 & 2 \\
\hline Wouri Bridge & 6.16 & 23 & 80 & 2 & & 2 & & \\
\hline Wouri Bridge & 6.25 & 18 & 120 & 3 & 1 & 2 & & \\
\hline Wouri Bridge & 6.47 & 5 & 230 & 6 & 4 & 1 & 1 & \\
\hline Wouri Bridge & 6.33 & 13 & 110 & 2 & 1 & 1 & & \\
\hline Wouri Bridge & 5.82 & 43 & 150 & 3 & 3 & & & \\
\hline Wouri Bridge & 6.06 & 29 & 160 & 9 & 4 & 3 & 2 & \\
\hline Wouri Bridge & 5.9 & 39 & 140 & 6 & 1 & 3 & 2 & \\
\hline Wouri Bridge & 5.76 & 49 & 150 & 9 & 4 & 4 & 1 & \\
\hline Wouri Bridge & 6.09 & 25 & 130 & 3 & 1 & 1 & 1 & \\
\hline Wouri Bridge & 6.18 & 22 & 40 & 5 & 4 & 1 & & 1 \\
\hline Essengue & 6.04 & 27 & 30 & 8 & 3 & 1 & 4 & \\
\hline Essengue & 5.85 & 36 & 20 & 7 & 2 & 4 & 1 & \\
\hline Essengue & 5.66 & 36 & 20 & 8 & 5 & 2 & 1 & \\
\hline Essengue & 5.72 & 45 & 10 & 3 & 3 & & & 1 \\
\hline
\end{tabular}


TABLE I

(Continued)

\begin{tabular}{|c|c|c|c|c|c|c|c|c|}
\hline Site & $\mathrm{pH}$ & $\begin{array}{l}\text { Conductivity } \\
\qquad(\mathrm{mV})\end{array}$ & $\begin{array}{l}\text { Height } \\
(\mathrm{cm})\end{array}$ & $\begin{array}{c}\text { Total } \\
\text { number of } \\
\text { specimens }\end{array}$ & Male & $\begin{array}{c}\text { Non-ovigerous } \\
\text { female }\end{array}$ & $\begin{array}{l}\text { Ovigerous } \\
\text { female }\end{array}$ & Juvenile \\
\hline Essengue & 6.07 & 25 & 120 & 13 & 8 & 5 & & \\
\hline Essengue & 6.08 & 23 & 80 & 8 & 5 & 3 & & \\
\hline Essengue & 5.46 & 60 & 100 & 9 & 5 & 4 & & \\
\hline Essengue & 6.1 & 23 & 100 & 9 & 8 & 1 & & \\
\hline Essengue & 6.06 & 25 & 110 & 15 & 11 & 3 & 1 & \\
\hline Essengue & 6.14 & 20 & 120 & 18 & 10 & 8 & & \\
\hline
\end{tabular}

Axil water $\mathrm{pH}$ and conductivity, height (= height from the ground), total number of specimens, and sexual assemblage are presented.

role (Fusi et al., 2016). Crabs, in particular, have a wide range of adaptations that allow them to colonize niches created by the complex interaction of vegetation structure and tidal regime (Kristensen, 2008; Nagelkerken et al., 2008; Sousa \& Dangremond, 2011; Simoni et al., 2013). Furthermore, they play a pivotal role in mangrove ecosystem resilience (Cannicci et al., 2008; Kristensen, 2008; Lee, 2008, 2015; Dahdouh-Guebas et al., 2011; Ng et al., 2015).

Our data described the presence of Platychirarma buettikoferi in all leaf axils of Pandanus candelabrum examined. Although this species has already been recorded in Cameroon (Manning \& Holthuis, 1981 and ref. of Mr. Powell within, on p. 351; Ngo-Massou et al., 2012; Fusi et al., 2016), its close association with $P$. candelabrum described here in detail, and therefore its phytotelmic habit, has not previously been reported. Many animals use $P$. candelabrum for various purposes, for example shelter and food (Grubb, 1971; Lounibos, 1979; Lee, 1985; Braithwaite \& Lonsdale, 1987; Verbeek et al., 1993; Cumberlidge et al., 2005), but $P$. buettikoferi seems to exclusively exploit the microhabitat formed by the complex leaf clusters. A similar adaptation has been described for another sesarmid species, Scandarma lintou, found to strictly co-occur with Pandanus odoratissimus L. f., 1782, in southern Taiwan, in close proximity to streams or freshwater pools sheltered from strong winds (Schubart et al., 2003).

$P$. candelabrum leaves provide $P$. buettikoferi with a freshwater habitat that is physico-chemically different from the pore water of the sediment. Although $\mathrm{pH}$ was variable, the leaf axil water had a higher conductivity than the ground water, indicating the presence of more solutes. This reinforces that this aquatic microhabitat can be more stable (i.e., more able to buffer change in $\mathrm{pH}$ ) than ground water, thereby avoiding potential stress for P. buettikoferi. P. candelabrum leaf axils were also found to collect potentially important food sources for this sesarmid, such as propagules of the taller Avicennia sp. trees as well as leaves and 

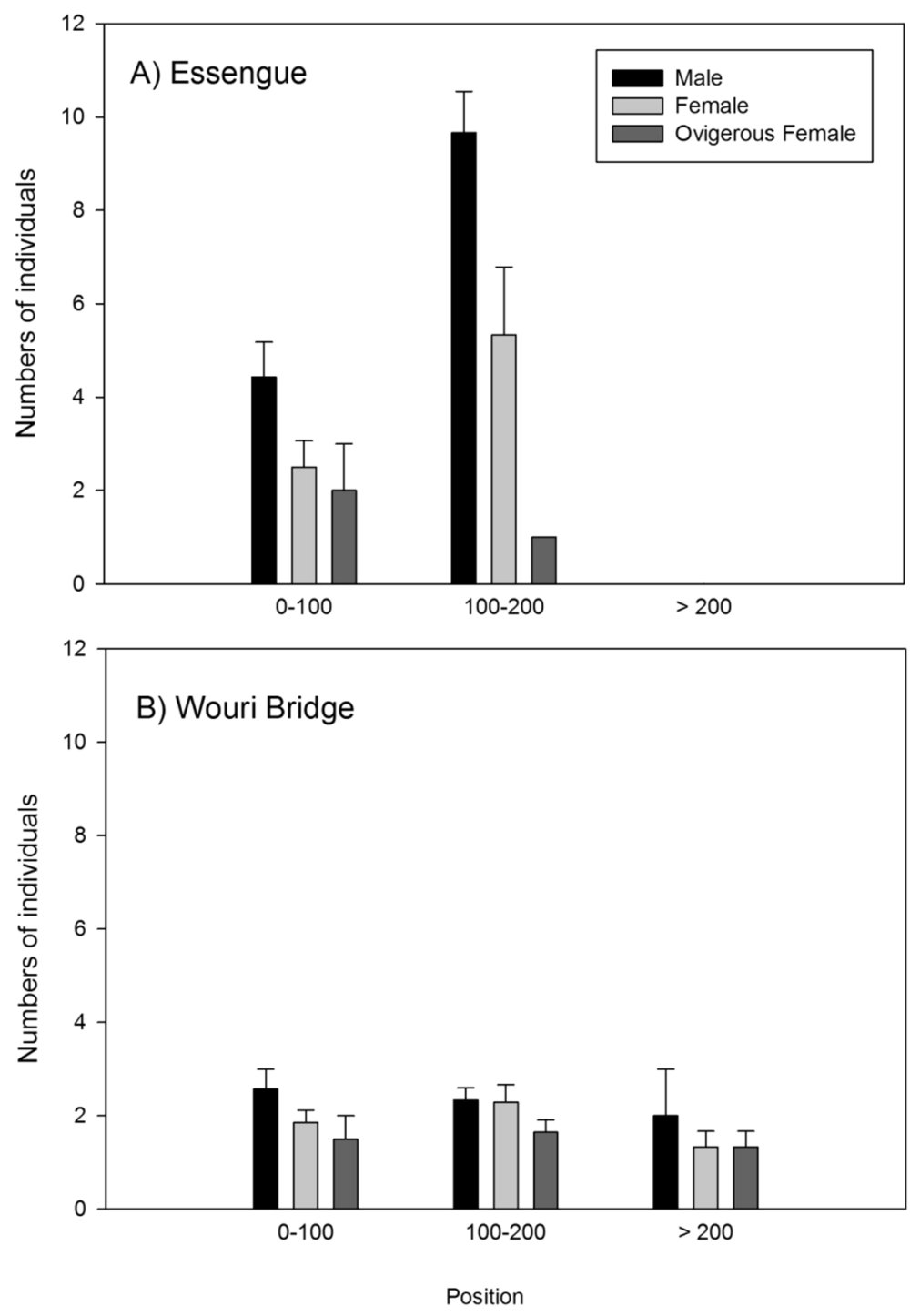

Fig. 3. Average number of Platychirarma buettikoferi (De Man, 1883) specimens found in Pandanus candelabrum P. Beauv. leaf clusters at three different heights from the ground, in: A, Essengue Forest $(N=10)$; and $\mathrm{B}$, Wouri bridge Forest $(N=37)$. Data are expressed as mean \pm standard error.

other mangrove litter (Sousa \& Dangremond, 2011). Additionally, we consistently found males, females and ovigerous females in every cluster analysed. Faecal pellets were found in almost all of the axils analysed, which suggests a high fidelity to the leaf. The leaf clusters could also provide refuge from the high predation pressure exerted by the mudskipper Periophthalmus papilio (Bloch \& Schneider, 


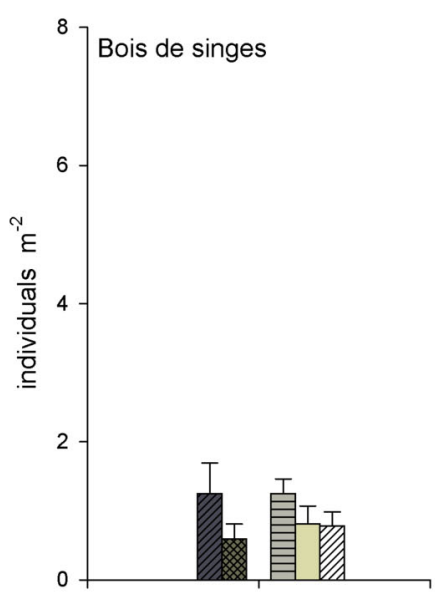

Rhizophora

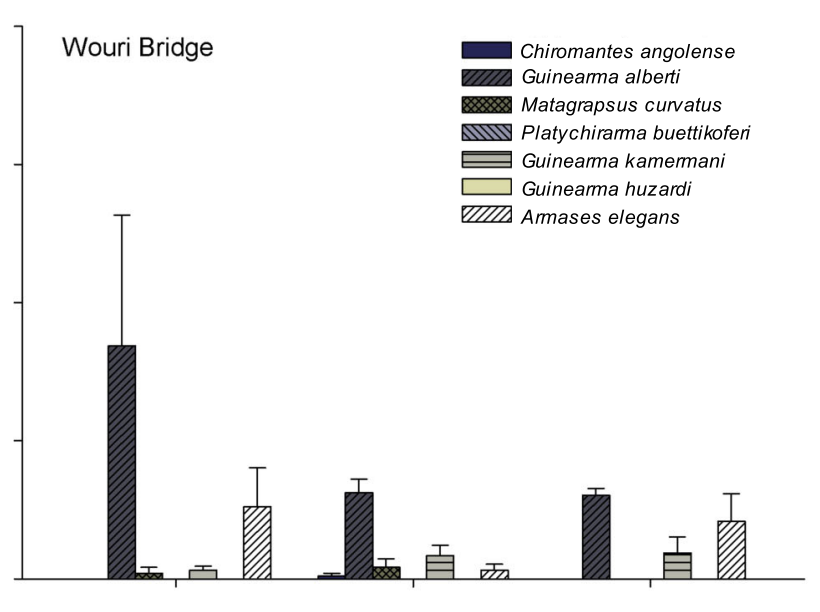

Avicennia

Pandanus

Rhizophora

Fig. 4. Mangrove macrobenthos density in the study sites expressed as mean \pm standard error; ( $N=6$ for each site). Data not available for Essengue forest (see Material and Methods section).

1801), found in very high densities in WB on the forest floor (Etim et al., 1996), and other predators (Cannicci et al., 1998).

The coincident distribution of $P$. buettikoferi and P. candelabrum in the Wouri estuary mangroves suggests that this is a tight association. We found no specimens of P. buettikoferi in the mature forests dominated by Rhizophora spp. in the same area, such as Bois de Singes (fig. 4). This association is corroborated by a previous study that placed $P$. buettikoferi at the landward side of mangrove forests and did not describe the species as a true mangrove crab (Rathbun, 1921). Furthermore, we found no specimens of $P$. buettikoferi throughout one month of observation, while other sesarmids were abundant such as Chiromantes angolense (de Brito Capello, 1864), Guinearma alberti (Rathbun, 1921), Metagrapsus curvatus (H. Milne Edwards, 1837), Guinearma kamermani (De Man, 1883), Guinearma huzardi (Desmarest, 1825) and Armases elegans (Herklots, 1851) (fig. 4).

The adaptation to live in a pioneering plant such as $P$. candelabrum seems to be convergent among different crab species, as documented for Metapaulias depressus in Jamaica (Schubart, 2007), Malagasya goodmani (Cumberlidge, Boyko \& Harvey, 2002) and the sesarmid Labuanium gracilipes (H. Milne Edwards, 1854) in Madagascar (Cumberlidge et al., 2005), Geosesarma foxi (Kemp, 1918) and Geosesarma serenei (Ng, 1986) in Penang, Peninsular Malaysia (Ng, 2017), and Geosesarma batak (Manuel-Santos, Ng \& Freitag, 2016), in central-southern Palawan Island and Geosesarma tagbanua (Manuel-Santos, Ng \& Freitag, 2016), in central-northern Palawan Island, in the Philippines (Manuel-Santos et al., 2016). In the present study, we could not prove that $P$. buettikoferi is a strictly phytotelmic 

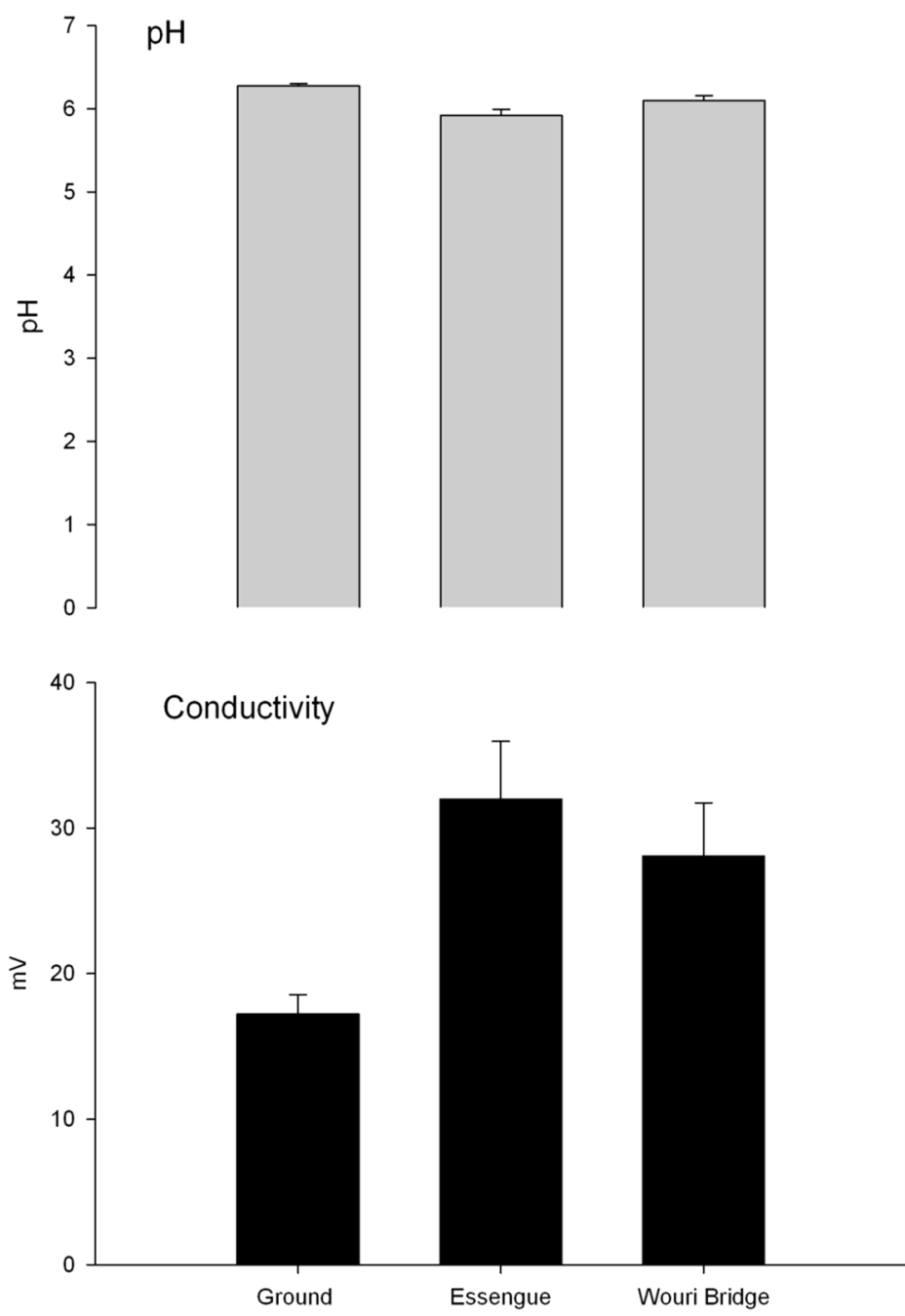

Fig. 5. The $\mathrm{pH}$ and conductivity of ground water (taken at ground level) and phytotelma Pandanus candelabrum P. Beauv. water at the two study sites. Data are expressed as mean \pm standard error. $N=14$ for Wouri Bridge and $N=10$ for Essengue for $\mathrm{pH}$; and $N=12$ for Wouri Bridge and $N=10$ for Essengue, for Conductivity.

species, but our findings suggest that the vegetation shift induced by human disturbance can at least offer a phytotelmic habitat to this crab species. In fact, the colonization of phytotelmata could also be the proximate factor behind the evolution of its flat chelipeds, unique to P. buettikoferi and very rare in the Sesarmidae (fig. 2). Indeed, a flat cheliped can help this crab hide within the leaf axils of $P$. candelabrum and, more generally, better exploit the shelter that this vegetation provides (fig. 2A). A similar characteristic has been observed in the crab S. lin- 
tou living in Pandanus odoratissimus, that exhibits conspicuously flattened fingers (Schubart et al., 2003). The permanent presence of water in these microhabitats could represent a physiological advantage for $P$. buettikoferi, providing a safe habitat in which to excrete catabolites while avoiding desiccation (Anger, 1995) and representing a water source to brood embryos (Cannicci et al., 2011; Vogt, 2013). To confirm the phytothelmic behaviour, the occurrence of ovigerous females is another proof that corroborates our result, although further investigations of egg sizes and the larval development are needed (Anger, 1995; Diesel, 1997).

In conclusion, we reveal a previously undescribed, possibly facultative, phytotelmic habit of $P$. buettikoferi, which may enable this species to colonize mangrove areas occupied by $P$. candelabrum.

\section{ACKNOWLEDGEMENTS}

This study was supported by the Cameroon Oil Transportation Company (COTCO). We are particularly thankful to Prof. Peter Ng and anonymous reviewers for constructive reading of the manuscript. We thank Bachirou Fewou for the logistic help in Douala.

\section{REFERENCES}

Alemagi, D., 2007. The oil industry along the Atlantic coast of Cameroon: assessing impacts and possible solutions. Resour. Policy, 32: 135-145. DOI:10.1016/j.resourpol.2007.08.007.

Anderson, M. J., R. N. GORLEy \& K. R. ClARKE, 2008. PERMANOVA+ for PRIMER: guide to software and statistical methods. (PRIMER-E Ltd., Plymouth).

ANGER, K., 1995. The conquest of freshwater and land by marine crabs: adaptations in life-history patterns and larval bioenergetics. J. Exp. Mar. Biol. Ecol., 193: 119-145. DOI:10.1016/00220981(95)00114-X.

Bartolini, F., F. Cimò, M. Fusi, F. Dahdouh-Guebas, G. P. Lopes \& S. Cannicci, 2011. The effect of sewage discharge on the ecosystem engineering activities of two east African fiddler crab species: consequences for mangrove ecosystem functioning. Mar. Environ. Res., 71: 53-61. DOI:10.1016/j.marenvres.2010.10.002.

BRAithWAite, R. W. \& W. M. LONSDALE, 1987. The rarity of Sminthopsis virginiae (Marsupialia: Dasyuridae) in relation to natural and unnatural habitats. Conserv. Biol., 1: 341-343.

Butchart, S. H. M., M. Walpole, B. Collen, A. van Strien, J. P. W. Scharlemann, R. E. A. Almond, J. E. M. Baillie, B. Bomhard, C. Brown, J. Bruno, K. E. Carpenter, G. M. CARr, J. Chanson, A. M. Chenery, J. Csirke, N. C. Davidson, F. DenTener, M. Foster, A. Galli, J. N. Galloway, P. Genovesi, R. D. Gregory, M. Hockings, V. Kapos, J.-F. Lamarque, F. Leverington, J. Loh, M. A. McGeoch, L. McRae, A. Minasyan, M. Hernández Morcillo, T. E. E. Oldfield, D. Pauly, S. Quader, C. Revenga, J. R. Sauer, B. Skolnik, D. Spear, D. Stanwell-Smith, S. N. Stuart, A. Symes, M. TIERnEy, T. D. TyRRELL, J.-C. ViÉ \& R. WATSON, 2010. Global biodiversity: indicators of recent declines. Science, 328: 1164-1168. DOI:10.1126/science.1187512. 
Cannicci, S., F. Bartolini, F. Dahdouh-Guebas, S. Fratini, C. Litulo, A. Macia, E. J. Mrabu, G. Penha-Lopes \& J. Paula, 2009. Effects of urban wastewater on crab and mollusc assemblages in equatorial and subtropical mangroves of east Africa. Estuar. Coast. Shelf Sci., 84: 305-317. DOI:10.1016/j.ecss.2009.04.021.

Cannicci, S., D. Burrows, S. Fratini, T. J. Smith, J. OfFenberg \& F. Dahdouh-Guebas, 2008. Faunal impact on vegetation structure and ecosystem function in mangrove forests: a review. Aquat. Bot., 89: 186-200. DOI:10.1016/j.aquabot.2008.01.009.

Cannicci, S., R. K. Ruwa, M. GiUggioli \& M. Vannini, 1998. Predatory activity and spatial strategies of Epixanthus dentatus (Decapoda: Oziidae), an ambush predator among the mangroves. J. Crust. Biol., 18: 57-63. DOI:10.2307/1549520.

CAnNicci, S., R. Simoni \& F. Giomi, 2011. Role of the embryo in crab terrestrialisation: an ontogenetic approach. Mar. Ecol. Prog. Ser., 430: 121-131. DOI:10.3354/meps08954.

Cumberlidge, N., C. B. Boyko \& A. W. Harvey, 2002. A new genus and species of freshwater crab (Crustacea, Decapoda, Potamoidea) from northern Madagascar, and a second new species associated with Pandanus leaf axils. J. Nat. Hist., 36: 65-77. DOI:10.1080/ 00222930010003800.

Cumberlidge, N., D. B. Fenolio, M. E. Walvoord \& J. Stout, 2005. Tree-climbing crabs (Potamonautidae and Sesarmidae) from phytotelmic microhabitats in rainforest canopy in Madagascar. J. Crust. Biol., 25: 302-308. DOI:10.1651/C-2532.

Dahdouh-Guebas, F., N. Koedam, B. Satyanarayana \& S. Cannicci, 2011. Human hydrographical changes interact with propagule predation behaviour in Sri Lankan mangrove forests. J. Exp. Mar. Biol. Ecol., 399: 188-200. DOI:10.1016/j.jembe.2010.11.012.

DIESEL, R., 1997. Maternal control of calcium concentration in the larval nursery of the bromeliad crab, Metopaulias depressus (Grapsidae). Proc. R. Soc., Lond., (B, Biol. Sci.), 264: 1403-1406. DOI:10.1098/rspb.1997.0195.

Din, N. \& F. BALTZER, 2008. Floristique et évolution des mangroves de l'estuaire du Cameroun. Africa Geosci. Rev., 1-2: 119-130.

Duke, N., J. O. Meynecke, S. Dittmann, A. M. Ellison, K. Anger, U. Berger, S. Cannicci, K. Diele, K. C. Ewel, C. D. Field, N. Koedam, S. Y. Lee, C. Marchand, I. Nordhaus \& F. DAhDOUH-GuEBAS, 2007. A world without mangroves? Science, 317: 41-43. DOI:10.1126/science.317.5834.41b.

ELLISON, A. M., 2008. Managing mangroves with benthic biodiversity in mind: moving beyond roving banditry. J. Sea Res., 59: 2-15. DOI:10.1016/j.seares.2007.07.001.

ELLISON, J. C. \& S. CANNICCI, 2016. Impacts and effects of ocean warming on mangrove species and ecosystems. In: D. LAFFOLEY \& J. M. BAXTER (eds.), Explaining ocean warming: causes, scale, effects and consequences, 135. (IUCN, Gland, Switzerland).

Etim, L., T. BreY \& W. ARntZ, 1996. A seminal study of the dynamics of a mudskipper (Periophthalmus papilio) population in the Cross River, Nigeria. Netherlands J. Aquat. Ecol., 30: 41-48. DOI:10.1007/BF02092146.

FISH, D., 1983. Phytotelmata: flora and fauna. In: J. H. FrAnK \& L. P. Lounibos (eds.), Phytotelmata: terrestrial plants as hosts for aquatic insect communities: 1-27. (Plexus Publishers, Medford, NJ, U.S.A.).

Fusi, M., G. M. Beone, N. A. Suciu, A. Sacchi, M. Trevisan, E. Capri, D. Daffonchio, N. Din, F. Dahdouh-Guebas \& S. CAnNiCCi, 2016. Ecological status and sources of anthropogenic contaminants in mangroves of the Wouri River Estuary (Cameroon). Mar. Pollut. Bull., 109: 723-733. DOI:10.1016/j.marpolbul.2016.06.104.

GRubB, P., 1971. Ecology of terrestrial decapod crustaceans on Aldabra. Philos. Trans. R. Soc. Lond., (B. Biol. Sci.) 260: 411-416.

Halpern, B. S., S. Walbridge, K. A. Selkoe, C. V. Kappel, F. Micheli, C. D’Agrosa, J. F. Bruno, K. S. Casey, C. Ebert, H. E. Fox, R. Fujita, D. Heinemann, H. S. Lenihan, 
E. M. P. Madin, M. T. Perry, E. R. Selig, M. Spalding, R. Steneck \& R. Watson, 2008. A global map of human impact on marine ecosystems. Science, 319: 948-952. DOI:10. 1126/science.1149345.

Hutchison, J., A. Manica, R. Swetnam, A. Balmford \& M. Spalding, 2014. Predicting global patterns in mangrove forest biomass. Conserv. Lett., 7: 233-240. DOI:10.1111/conl. 12060 .

Kristensen, E., 2008. Mangrove crabs as ecosystem engineers; with emphasis on sediment processes. J. Sea Res., 59: 30-43. DOI:10.1016/j.seares.2007.05.004.

LAessle, A. M., 1961. A micro-limnological study of Jamaican bromeliads. Ecology, 42: 499-517. DOI:10.2307/1932236.

LEE, M. A. B., 1985. The dispersal of Pandanus tectorius by the land crab Cardisoma carnifex. Oikos, 45: 169-173. DOI:10.2307/3565702.

LEE, S. Y., 2008. Mangrove macrobenthos: assemblages, services, and linkages. J. Sea Res., 59: 16-29. DOI:10.1016/j.seares.2007.05.002.

Lounibos, L., 1979. Mosquitoes occurring in the axils of Pandanus rabaiensis Rendle on the Kenya coast. Cah. ORSTOM, (Ser. Entomol. Med. Parasitol.) XVII: 25-29.

Manning, R. B. \& L. B. Holthuis, 1981. West African brachyuran crabs (Crustacea: Decapoda). Smithson. Contrib. Zool., 306: 1-396. DOI:10.5479/si.00810282.306.

Mohamed, M. O. S., G. Neukermans, J. G. Kairo, F. Dahdouh-Guebas \& N. Koedam, 2008. Mangrove forests in a peri-urban setting: the case of Mombasa (Kenya). Wetl. Ecol. Manag., 17: 243-255. DOI:10.1007/s11273-008-9104-8.

Monod, T., 1956. Hippidea et Brachyura ouest-africains. Mémoires de l'Institut Français d'Afrique Noire, 45: 1-674. (IFAN, Dakar, Senegal).

Nagelkerken, I., S. J. M. Blaber, S. Boulllon, P. Green, M. Haywood, L. G. Kirton, J.-O. Meynecke, J. Pawlik, H. M. Penrose, A. Sasekumar \& P. J. Somerfield, 2008. The habitat function of mangroves for terrestrial and marine fauna: a review. Aquat. Bot., 89: 155-185. DOI:10.1016/j.aquabot.2007.12.007.

Nfotabong-Atheull, A., N. Din \& F. Dahdouh-Guebas, 2013. Qualitative and quantitative characterization of mangrove vegetation structure and dynamics in a peri-urban setting of Douala (Cameroon): an approach using air-borne imagery. Estuaries and Coasts, 36: 11811192. DOI:10.1007/s12237-013-9638-8.

Nfotabong-Atheull, A., N. Din, L. G. Essomè Koum, B. Satyanarayana, N. Koedam \& F. DAHDOUh-GueBAS, 2011. Assessing forest products usage and local residents' perception of environmental changes in peri-urban and rural mangroves of Cameroon, central Africa. J. Ethnobiol. Ethnomed., 7: 41. DOI:10.1186/1746-4269-7-41.

Nfotabong-Atheull, A., N. Din, S. N. Longonje, N. Koedam \& F. Dahdouh-Guebas, 2009. Commercial activities and subsistence utilization of mangrove forests around the Wouri estuary and the Douala-Edea reserve (Cameroon). J. Ethnobiol. Ethnomed., 5: 35. DOI:10. 1186/1746-4269-5-35.

Ngo-Massou, V., G. Essome-Koum, E. Ngollo-Dina \& N. Din, 2012. Composition of macrobenthos in the Wouri River estuary mangrove, Douala, Cameroon. African J. Mar. Sci., 34: 349-360. DOI:10.2989/1814232X.2012.725288.

Penha-Lopes, G., P. Torres, S. Cannicci, L. Narciso \& J. Paula, 2011. Monitoring anthropogenic sewage pollution on mangrove creeks in southern Mozambique: a test of Palaemon concinnus Dana, 1852 (Palaemonidae) as a biological indicator. Environ. Pollut., 159: 636-645. DOI:10.1016/j.envpol.2010.09.029.

SAENGER, P., 2012. Ecological and social consequences of the void in mangrove conservation. Bioscience, 62: 204-205. DOI:10.1525/bio.2012.62.2.15.

Saenger, P., F. Basco, N. Din, P. R. Jules \& D. D. Siegfried, 2008. Logging activities in mangrove forests: a case study of Douala Cameroon. African J. Environ. Sci. Technol., 2: 2230 . 
SCHEREN, P. A., 2002. Environmental pollution in the Gulf of Guinea - a regional approach. 44: 633-641.

SCHUBART, C. D., 2007. The social breeding system of the Jamaican bromeliad crab Metopaulias depressus. In: J. E. DufFY \& C. M. THIEL (eds.), Evolutionary ecology of social and sexual systems: crustaceans as model organisms: 560. (Oxford University Press, Oxford, U.K.).

Shahdadi, A., P. A. Mvogo Ndongo, T. Suess \& C. D. Schubart, 2019. Reappraisal and redescription of the three species of the recently defined genus Guinearma Shahdadi \& Schubart, 2017, with a key to the west African Sesarmidae (Decapoda, Brachyura). Crustaceana, 92. DOI:10.1163/15685403-00003863.

Simoni, R., F. Giomi, D. Spigoli, H.-O. Pörtner \& S. CANnicCI, 2013. Adaptations to semiterrestrial life in embryos of east African mangrove crabs: a comparative approach. Mar. Biol., 160: 2483-2492. DOI:10.1007/s00227-013-2243-3.

Skov, M. W., M. VAnnini, J. P. Shunula, R. G. HaRtnoll \& S. CAnnicCi, 2002. Quantifying the density of mangrove crabs: Ocypodidae and Grapsidae. Mar. Biol., 141: 725-732. DOI:10. 1007/s00227-002-0867-9.

SousA, W. P. \& E. M. DANGREMOND, 2011. Trophic interactions in coastal and estuarine mangrove forest ecosystems. In: J. G. WILSON \& J. J. LUCZKOVICH (eds.), Trophic relationships of coastal and estuarine ecosystems. Treatise on Estuarine and Coastal Science, 6: 43-93. (Academic Press, London).

Tomlinson, P. B., 1986. The botany of mangroves: 1-413. (Cambridge Tropical Biology Series; Cambridge University Press, Cambridge, U.K.).

UNEP, 2007. Mangroves of western and central Africa: 1-87. (Earthprint, Chicago, IL).

VALIELA, I., J. L. BOWEN \& J. K. YORK, 2001. Mangrove forests: one of the world's threatened major tropical environments. Bioscience, 51: 807. DOI:10.1641/0006-3568(2001)051[0807: MFOOTW]2.0.CO;2.

Verbeek, N., R. Braithwaite \& R. BoAsson, 1993. The importance of Pandanus spiralis to birds. Emu, 93: 53-58.

VoGT, G., 2013. Abbreviation of larval development and extension of brood care as key features of the evolution of freshwater Decapoda. Biol. Rev. Camb. Philos. Soc., 88: 81-116. DOI:10. 1111/j.1469-185X.2012.00241.X.

Worm, B., E. B. Barbier, N. Beaumont, J. E. Duffy, C. Folke, B. S. Halpern, J. B. C. Jackson, H. K. Lotze, F. Micheli, S. R. Palumbi, E. Sala, K. A. Selkoe, J. J. STACHOWICZ \& R. WATSON, 2006. Impacts of biodiversity loss on ocean ecosystem services. Science, 314: 787-790. DOI:10.1126/science.1132294.

First received 20 May 2019.

Final version accepted 30 June 2021. 